\title{
Enhancement of poultry meat: Trends, nutritional profile, legislation and challenges
}

\author{
S. M. Tan', H. L. de Kock¹, G. A. Dykes², R. Coorey² \& E. M. Buys ${ }^{1 \#}$ \\ ${ }^{1}$ Department of Food Science, University of Pretoria, Private Bag x 20, Hatfield, Pretoria 0028, South Africa \\ ${ }^{2}$ School of Public Health, Curtin University, Bentley 6102, Western Australia, Australia
}

(Received 21 August 2017; Accepted 16 November 2017; First published online 4 December 2017)

\begin{abstract}
Copyright resides with the authors in terms of the Creative Commons Attribution 4.0 South African Licence.
See: http://creativecommons.org/licenses/by/4.0/za

Condition of use: The user may copy, distribute, transmit and adapt the work, but must recognise the authors and the South African Journal of Animal Science.
\end{abstract}

\begin{abstract}
Poultry meat is a good source of animal protein, and is affordable for many low-income families in developing countries. It is also part of a balanced diet through contributing valuable nutrients for human health. The poultry industry implements an enhancement process to improve quality and add value to poultry meat. This process may be defined as the addition of a formulated solution or brine, which contains salt, phosphate, and flavour additives for meat. It reduces cooking loss, and improves the tenderness and juiciness of meat. Although enhancement is widely used in the poultry industry, literature on this topic is inadequate. This review aims to outline recent trends in poultry meat enhancement, the main ingredients, and the effects of these ingredients on enhanced poultry meat. The nutritional profile affected by enhancement, the challenges of the enhancement process, and the legislative background to enhancement in selected countries are also discussed. This review provides scientific information on poultry meat enhancement for authorities, food processors, and consumers to ensure accurate application of the process and to prevent adulterated meat products in the market.
\end{abstract}

Keywords: Brine, food regulations, meat safety, nutrient components

\#Corresponding author: elna.buys@up.ac.za

\section{Introduction}

Nearly half of the governments throughout the world are dealing with a nutrition transition in which undernourished consumers co-exist with a rising incidence of obese populations owing to unequal socioeconomic development (Joubert et al., 2007). Protein-energy malnutrition remains a persistent problem in some developing countries because of the high price of meat, which is not affordable for low-income families. Meat is a highly nutritious and versatile food. Its primary importance as a food is that its proteins are easily broken down to amino acids during digestion and are readily accessible for cell growth and repair. In lowincome developing countries, such as those in South Asia and sub-Saharan Africa, meat is less frequently consumed and less often available as a protein source in diets (Food and Agriculture Organization of the United Nations (FAO), 2012). A survey showed that $34 \%$ of the population in South Asia and $59 \%$ of the population in sub-Saharan Africa obtained their energy from staple foods such as cereals, grain legumes and starchy roots (Smith \& Wiesman, 2007). Some of these staple foods are deficient in the essential amino acids that are required by human beings, for example lysine, threonine, sulphur-bearing amino acids (methionine and cysteine), and occasionally tryptophan, which may lead to protein deficiency (Juliano, 1993). Poultry, particularly chicken meat, is currently one of the best sources of animal protein for low-income populations because it is an affordable and accessible source of protein with low fat content and limited religious restrictions (Smith \& Wiesman, 2007; Association of Poultry Processors and Poultry Trade in the EU (AVEC), 2016). Because of these advantages, the global consumption of poultry meat, especially chicken meat, is greater than that of other meats (Belova et al., 2012; Pandurevic et al., 2014; Rural Industries Research and Development Corporation (RIRDC), 2014). In addition, the growth of the poultry 
industry in developing countries provides opportunities for employment and improves the country's economy (Smith \& Wiesman, 2007).

World poultry meat consumption is predicted to exceed that of pork in 2020 and to increase by $27 \%$ in 2023 (AVEC, 2016). Consumption of poultry meat in the EU was $22.5 \mathrm{~kg}$ per capita in 2015 (AVEC, 2016), while in the USA the consumption of poultry was reported to be $40.5 \mathrm{~kg}$ per capita in the same year (United States Department of Agriculture (USDA), 2016). The consumption of poultry meat in developed countries has increased at a slower rate than that in developing countries. This is owing to rapid population growth, urbanization, and lifestyle factors that contribute to a higher protein intake of and demand for poultry meat in the developing countries (Belova et al., 2012). In sub-Saharan Africa, the largest producer of chicken meat is South Africa with a consumption of $37.47 \mathrm{~kg}$ per capita per year in 2014 (South African Poultry Association (SAPA), 2015). The dominance of chicken meat in the South African meat market is due to similar factors to those driving chicken demand globally and the price of chicken meat is generally lower than that of other meats (Department of Agriculture, Forestry \& Fisheries (DAFF), 2013).

A rapid growth in the consumption of poultry meat requires effective and efficient food processing to produce good quality meat products. The poultry industry enhances poultry meat to improve its tenderness, juiciness, flavour and shelf life for consumers (Brewer et al., 2002; Hayes et al., 2006). Poultry meat enhancement is defined as the addition of a formulated solution or brine that contains water, salt, phosphates, and flavour additives to maintain the tenderness and juiciness of meat during cooking (American Meat Institute, 2007). Each of the ingredients in the enhancement solution provides specific functions. For example, phosphates aid in water retention and maintain the juiciness in meat; salt is added to increase water binding ability; and flavour additives provide desirable flavours for consumers (Smith \& Acton, 2001). Enhanced meat usually contains $15 \% \mathrm{w} / \mathrm{w}$ (sometimes up to $30 \%$ ) enhancement solution or brine, depending on the poultry manufacturers (AVEC, 2016). The addition of brine to meat increases the weight of the meat, reduces water loss during cooking, and enhances overall quality (Alvarado \& McKee, 2007). Because the price of poultry meat is based on weight, this makes products more affordable to consumers or benefits meat producers from the sale of water at meat prices. The large meat companies in the US have markedly increased the production of moisture-enhanced pork, beef, and poultry, which are pre-packaged for case-ready merchandising (Xiong, 2005). In the US, approximately $23 \%$ of chicken meat is enhanced and enhanced meat products represent $21 \%$ of all packaged meat in the market (American Meat Institute, 2007). The Association of Poultry Processors and Poultry Trade (AVEC, 2016) reported that in 2015 the EU imported $255931 \mathrm{~kg}$ of processed meat (salted, brined, smoked and dried) from other countries. A total of 85\% of frozen chicken in the South African market has been injected with $15 \%$ to $30 \%$ brine solution (SAPA, 2015).

Although the enhancement process is used widely in the poultry industry in some countries, the information appears to be fragmented. This review, therefore, aims to outline and review current trends in the enhancement of poultry meat, the main ingredients and the role these ingredients play in the process. Moreover, the nutritional profile that is affected by enhancement, the challenges of the enhancement process, and the legislation of enhancement in US, EU, and selected developing countries in Africa are also discussed.

\section{Trends in brine-enhanced poultry meat}

Since 2000 B.C., meat preservation in brine has been practised in Mesopotamia, Egypt, China, and the Mediterranean region (Ensminger \& Ensminger, 1993). In the modern era, meat processing industries worldwide use methods such as immersion and injection of brine to improve the quality and texture of meat. Advanced applications such as pulsed vacuum, high pressure treatment and ultrasound are currently being researched in meat brining (Chiralt et al., 2001; Cárcel et al., 2007; Chemat et al., 2011).

\section{Injection and immersion with brine}

Brine injection entails the use of a multi-needle injector, which consists of a conveyer that introduces the meat to an injection head with two to four rows of needles (Varnam \& Sutherland, 1995). The meat is held by a clamp and is injected with the brine solution simultaneously by all needles and is then tumbled or massaged to ensure that the brine is evenly distributed throughout the muscle (Wilson, 2008; Egbert \& Payne, 2009). Multi-needle injectors are currently used in most large-scale operations. On the other hand, the immersion method entails immersing meat in brine solution and holding it for three to five days at $4{ }^{\circ} \mathrm{C}$ (Wilson, 2008). The meats are stacked in a large tank and the brine is then run into the tank to completely cover the meat surfaces (Varnam \& Sutherland, 1995). The important difference between immersion and injection of brine is that the immersion method is continuous (Varnam \& Sutherland, 1995). Nevertheless, multi-needle injection is currently the most widely used method in the meat industry because the exact 
quantity of brine can be dosed and it ensures consistent meat quality without the time loss required by immersion (Xargayó et al., 2001).

Although immersion and injection methods with brine improve meat quality, they take from three days to weeks to achieve the desired attributes (Wilson, 2008). To achieve accuracy and efficiency, the food industry is searching for alternative technologies to improve mass transfer kinetics between the brine solution and the protein matrix of meat. Advanced applications such as pulsed vacuum brining, high pressure treatment, and high intensity ultrasound brining are currently important research areas (Chiralt et al., 2001; Deumier et al., 2003; Cárcel et al., 2007; Villacís et al., 2008).

\section{Pulsed vacuum brining}

Pulsed vacuum techniques may be regarded as a step up from immersion. Pulsed vacuum brining allows pressure to fluctuate alternately between vacuum and atmospheric pressure during brining (Deumier et al., 2003). This promotes infiltration of the brine solution into the meat by forcing out entrapped gases in the meat when the vacuum is applied. On return to atmospheric pressure, the brine solution penetrates the pores from which the gases were expelled (Fito \& Pastor, 1994; Chiralt et al., 2001; Deumier et al., 2003). There is limited literature on the use of this process on poultry meat. Pulsed vacuum brining of turkey breast meat has better mass transfer compared with atmospheric brining (Deumier et al., 2003). Wang et al. (2016) reported that pulsed vacuum brining improved brining efficiency, actomyosin dissociation, myofibril expansion and water-holding capacity in lamb. This technology could be commercialized and practised in large-scale operations in the meat industry.

\section{High pressure treatment}

Application of high pressure treatment in meat processing was initially investigated for microbial inactivation, meat tenderization, gelation and limiting lipid oxidation (Lamballeric-Anton et al., 2002). In recent years, the application of high pressure has been reported to accelerate the diffusion of brine into meat. Villacís et al. (2008) found that high pressure treatment at $150 \mathrm{MPa}$, with a holding time of 20 minutes, resulted in a tenfold increase in the salt $(\mathrm{NaCl})$ diffusion coefficient in turkey meat compared with atmospheric pressure brining. Water uptake and sodium chloride diffusivity were increased when chicken breast samples were brined at $150 \mathrm{MPa}$, which was the recommended pressure, because a further increase in pressure decreased its efficiency (Leng et al., 2013). Brining at $150 \mathrm{MPa}$ improves water-holding capacity and enhances meat texture (Leng et al., 2013). In addition, Jin et al. (2014) reported that pulsed pressure treatment at $150 \mathrm{kPa}, 12$ pressure pulses with a holding time of 40 minutes, effectively shortened $30 \%$ of the brining time and still achieved the same salt diffusion coefficient comparable with atmospheric pressure brining samples. High pressure treatment has also been used recently in salt reduction studies in cooked ham (Pietrasik et al., 2016; Tamm et al., 2016). Nevertheless, one of the biggest drawback in high pressure processing is the discoloration of meat and this is commercially unacceptable (Bajovic et al., 2012). Research is currently being carried out to overcome the drawbacks to ensure high pressure treatment can be used as a processing aid in improving the mass transfer of brine into meat commercially (Guyon et al., 2016).

\section{Ultrasound treatment}

The use of ultrasound technologies in the food industry has been the focus of research in recent years. The growing interest in ultrasound technologies is due to their reliability and because they appeal to companies that are interested in environmental sustainability (Awad et al., 2012). Ultrasound is applied in brining by submerging food products in an ultrasonic bath (Chemat et al., 2011). Pork loin samples that were immersed in $\mathrm{NaCl}$ brine with various intensities of ultrasound treatments showed higher water and $\mathrm{NaCl}$ uptakes compared with the non-sonicated samples (Cárcel et al., 2007). Hatloe (1995) reported that the application of ultrasound reduced salting time, crust formation and unwanted colouring in raw meat. The application of ultrasound is also being studied in the cheese industry to improve organoleptic quality and product stability (Sanchez et al., 1999). However, there is still a dearth of literature on ultrasound treatment in enhancing poultry meat.

The principal aims of these technologies are to reduce processing time, save energy, and improve the quality of meat products. They have the potential to produce high-quality safe food products. Current limitations in implementing these technologies on an industrial scale include high investment costs, lack of full control of variables associated with the process operation, lack of regulatory approval and insufficient knowledge of consumer acceptance (Chemat et al., 2011; Awad et al., 2012).

\section{Effects of enhancement solution on muscle structure}


The main ingredients of a typical enhancement solution are water, salt and phosphates (Xiong, 2005; Alvarado \& McKee, 2007; Gill et al., 2009). Water is added to provide moisture to reduce cooking loss (Gómez et al., 2015). It also acts as a solvent in conjunction with phosphates and salt for muscle protein solubilization by allowing the diffusion of sodium and phosphate ions in the meat matrix (Feiner, 2006; Gómez et al., 2015). These diffuse into the muscle fibre cells because the solution contains a higher concentration of salt and phosphate than the cells (Sabadini et al., 1998; Wang et al., 2000). The salt and phosphate ions in the cells effectively increase the water retention capacity of muscles by dissociating the protein structure of muscle filaments and causing swelling of myofibrils (Graiver et al., 2006). The myofibril is the main structural component of meat muscle, which contains approximately $80 \%$ water and therefore is the site of water retention during meat processing (Offer \& Trinick, 1983). The effects of salt and phosphate on the myofibrils of meat muscles are shown in Figure 1. Salt enhances the swelling of protein structures, but it does not solubilize most of the filament proteins on its own (Knight \& Parsons, 1988; Ranken, 2000). Offer \& Trinick (1983) suggested that the chloride ions in $\mathrm{NaCl}$ primarily bind to the filaments and increase electrostatic repulsive forces. This allows the filament matrix to expand and form a larger gap between the actin and myosin in myofibrils. The addition of salt also causes a slight shift in the iso-electric point of muscle tissue towards a slightly acidic $\mathrm{pH}$, which increases the water-binding ability (Feiner, 2006). The salt concentration in the enhancement solution or brine influences the chemical gradients, the water-holding capacity and the level of mass transfer of meat (Shi \& Le Maguer, 2002; Vestegaard et al., 2005). At low salt concentration, the swelling of myofibrils with protein solubilization increases water-holding capacity, while a reverse effect was observed at high salt concentration owing to the insolubilization of proteins in meat muscle (Graiver et al., 2009; Nguyen et al., 2010). A final salt concentration of $0.8 \mathrm{M}$ to $1 \mathrm{M}$ (approximately 4.6 to $5.8 \%$ ) contributes to the maximum water uptake and the meat weight can be increased by more than $10 \%$ of its original weight (Xiong et al., 2000).
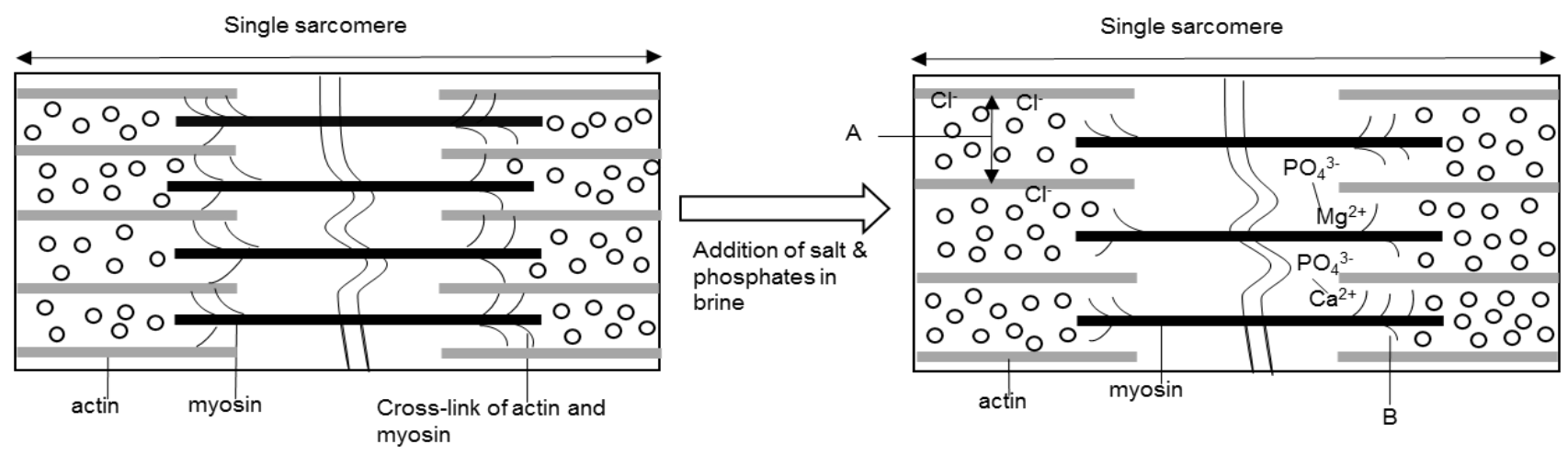

A: The chloride ions bind to the actin filaments and expand the filament matrix, therefore more water molecules can be retained in the meat matrix. B: Cross-links of actin and myosin are neutralized due to the binding of negatively charged phosphate ions to the positively charged calcium and magnesium ions in myofibrils.

Figure 1 Effects of salt and phosphate ions in enhancement solution on myofibril of meat muscles.

On the other hand, phosphates remove the cross-links between actin and myosin fibrils and support the dissociation of the actomyosin complex into separate fibres (Figure 1) (Offer \& Knight, 1988; Puolanne et al., 2001). The separation of actin and myosin occurs during the binding of negatively charged phosphate ions to positively charged calcium and magnesium ions in the meat muscle (Feiner, 2006). Only phosphates are capable of separating actin and myosin, and this is their main use in the global meat industry (Feiner, 2006). A combination of sodium chloride and phosphates is therefore necessary in enhancement solutions to improve overall tenderness and juiciness of poultry meat. The maximum permitted level of phosphates (singly or in combination) in the global food industry is $0.5 \%$ of the weight of finished meat products (US Food Safety and Inspection Service (FSIS), 2016). Currently, sodium tripolyphosphate is the most commonly used ingredient in brine solutions because it is relatively inexpensive. It accounts for approximately $80 \%$ of the phosphates used in further-processed meat products (Alvarado \& McKee, 2007). Occasionally other functional and flavour additives supplement the enhancement solution to increase moisture uptake, reduce cooking loss and provide desirable flavours (Robbins et al., 2002; Davies et al., 2004; Xiong, 2005). Hydrocolloids, commonly referred to as 'gums', can form gels and act as thickeners in enhancing texture in meat products and reducing cooking loss (Feiner, 2006). Proteins, such as soy proteins, whey proteins and 
casein, are added to meat products to stabilize emulsions and bind water at molecular level to increase the firmness of meat (Feiner, 2006). Hydrolysed soy protein contributes to the water-holding capacity in meat due to its strong hydrophilicity of soy peptides (Adler-Nissen \& Olsen, 1979). Feng \& Xiong (2003) suggested that synergistic interactions of hydrolysed soy proteins with meat muscle proteins form a gel matrix, which is capable of immobilizing extraneous water and therefore retains water in meat. A summary of the functional ingredients in enhancement solutions is provided in Table 1.

Table 1 Ingredients in enhancement solutions and their functions

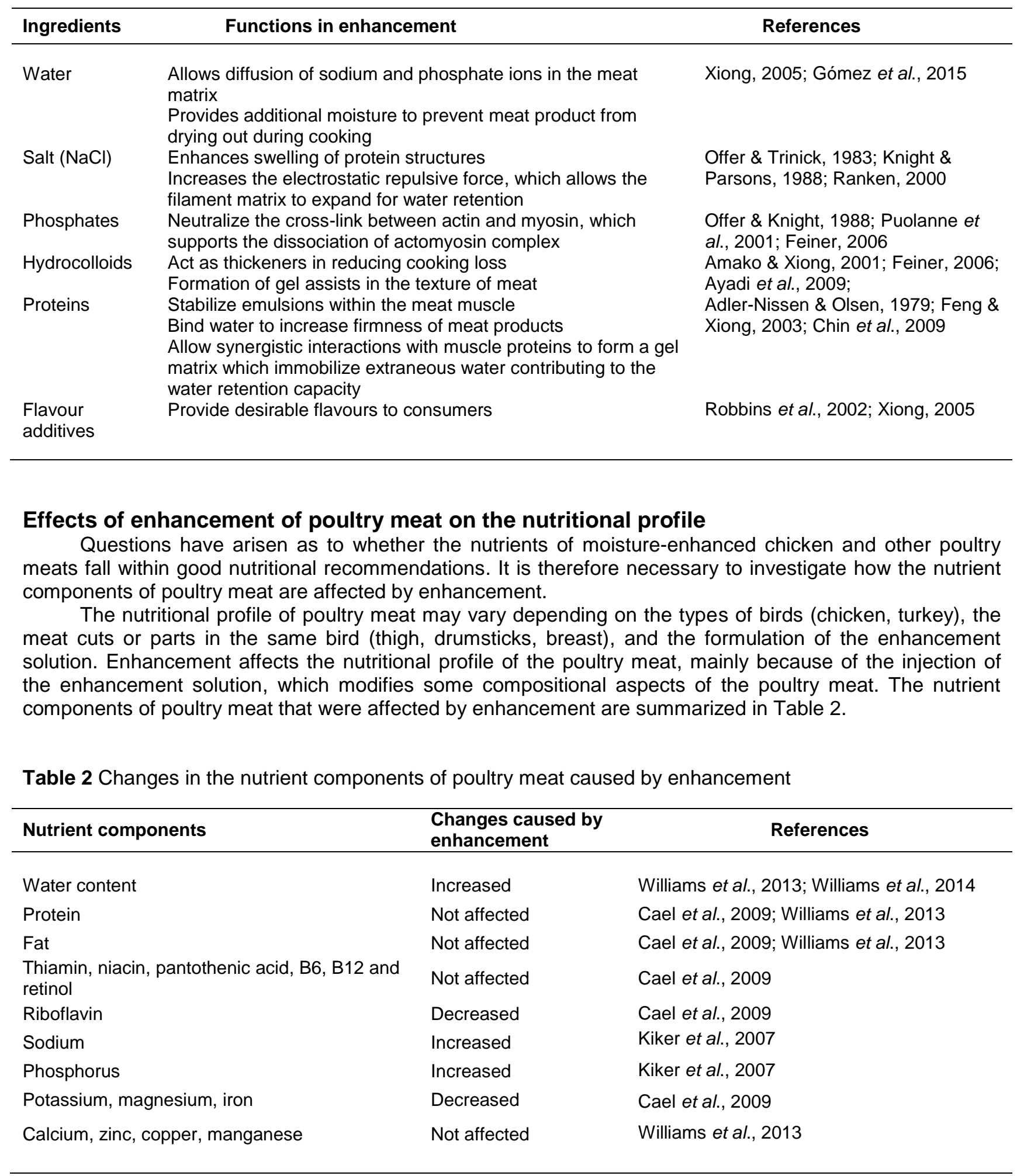




\section{Moisture, protein, fat and vitamins}

Williams et al. (2013) reported that the water content was increased, and the cooking loss reduced after skinless chicken fillets were treated with an $8 \%$ enhancement solution. Williams et al. (2014) reported that the water content of enhanced raw chicken fillets was higher than in the non-enhanced chicken fillets. However, the percentage of water in raw chicken fillets was not affected by enhancement in the studies by Kiker et al. (2007) and Cael et al. (2009). Theoretically, the water content should be increased in the enhanced meat because the salt and phosphate in the enhancement solution contribute to the water-holding capacity and improve tenderness (Xiong, 2005). Cael et al. (2009) and Williams et al. (2013) reported that the percentages of protein and fat $(20.50 \%$ and $2.66 \%$, respectively) were the same in raw enhanced and non-enhanced chicken fillets. Among the vitamins, thiamin, niacin, pantothenic acid, B6, B12, and retinol were unaffected by enhancement, but the level of riboflavin was lower $(P<0.05)$ in raw enhanced chicken breast fillets $(0.083 \mathrm{mg} / 100 \mathrm{~g})$ than in non-enhanced fillets $(0.10 \mathrm{mg} / 100 \mathrm{~g})$ (Cael et al., 2009).

\section{Minerals}

Among minerals, sodium is the main elevated nutrient in enhanced meat products. Salt and phosphate are the primary ingredients in brine. Therefore, the dietary sodium and phosphate content in enhanced meat is higher than in non-enhanced meat. The sodium and phosphorus contents were $50 \%$ and $26 \%$ higher after enhancement (Kiker et al., 2007). Cael et al. (2009) demonstrated that enhancement increases the phosphorus and sodium contents of chicken breast fillets by $24 \%$ and $178 \%$, respectively. Another study with turkey meat samples found that the sodium and phosphorus contents of enhanced samples were higher than non-enhanced samples (Williams et al., 2013). The effect of enhancement on the nutritional profile of meat may be influenced by the type of enhancement, the level of enhancement, and the types of meat. A $100 \mathrm{~g}$ serving of cooked enhanced poultry meat would supply $27.3 \%$ of the maximum recommended intake of salt and $37.4 \%$ of the daily value recommended for phosphorus (Kiker et al., 2007). Enhancement also affects the levels of potassium, magnesium, and iron in poultry meat. The potassium content of chicken was decreased by $24 \%$ when raw enhanced fillets and non-enhanced fillets were compared (Cael et al., 2009). Williams et al. (2013) demonstrated that the magnesium and iron levels in enhanced chicken breast fillets were lower $(21.01 \mathrm{mg} / 100 \mathrm{~g}$ and $0.70 \mathrm{mg} / 100 \mathrm{~g}$, respectively, $P<0.05)$ than those in non-enhanced fillets, namely $24.68 \mathrm{mg} / 100 \mathrm{~g}$ and $0.89 \mathrm{mg} / 100 \mathrm{~g}$, respectively. Other minerals such as calcium, zinc, copper and manganese were found to be unaffected by enhancement (Kiker et al., 2007; Cael et al., 2009; Williams et al., 2013).

The enhancement of poultry meat does not affect most of the nutrient components of poultry meat, with the exception of moisture, sodium and phosphorus. Enhanced meat with a significant increase in phosphorus and sodium content might affect the regular dietary intake of these two minerals in consumers. Consumers typically add salt to poultry products before or after cooking and the addition of salt to enhanced meat may lead to excessive sodium and phosphate intake, which would have serious public health implications such as high blood pressure, and kidney and cardiovascular diseases (De Kock et al., 2016).

\section{Legislation of poultry meat enhancement European Union}

Poultry meat and poultry products in the EU are regulated by the European Commission and assisted by the Association of Poultry Processors and Poultry Trade (AVEC). Council Directive 71/118/EEC regulates the production and marketing of fresh poultry meat, while Council Directive 94/65/EC governs the production of meat preparations (Council of the European Union, 1994). When other ingredients, such as marinades, water, seasoning and coatings, are added to poultry meat and the meat undergoes treatment that is insufficient to modify its internal cellular structure, the product is classified as a meat preparation. In a meat preparation, the product is placed in the market under Directive 94/65 (Council of the European Union, 1994). There is confusion over the extension of the interpretation of Article 5(1)(b) of Directive 71/118 to prohibit 'bulked up' fresh meat, which is defined as a meat preparation or a meat-based product and therefore contrary to the definition of a meat preparation under Article 2.2 of Directive 94/65. It could be wrongly interpreted by the industry that adding water as an ingredient in the manufacture of a meat preparation is legal. Attention has been drawn to the fraudulent practice of excessive addition of water in the European poultry industry after a survey in October 2000 by the British Food Standards Agency (FSA) revealed excessive amounts of added water in poultry meat (FSA, 2000). This was followed by a complaint by the Irish FSA to the EU Commission in May 2002 and another from the British FSA in March 2003, as well as the appearance of concerns in the media (The Guardian, 2013). Cases of excessive addition of brine in poultry via tumbling or injection by European manufacturers, particularly in Ireland and the United Kingdom, were 
reported to increase the weight of meat products by up to $40 \%$ of the original weight (FSA, 2000). The EU Commission and AVEC oppose the practice of adding water to poultry meat with the sole purpose of increasing the weight of the meat products (The Guarding, 2013). Nevertheless, the EU Commission sets strict laws and regulations on the labelling of these products, leaving the purchasing decision about enhanced meat products to the consumers. The industry and suppliers are required to specify the brine content on product labels, and declare net weight and quality grading before products can be marketed. In addition, the labelling of pre-packaged poultry meat intended for the final consumer must comply with the labelling requirements of Regulation (EU) No 1169/2011 (2011) and additional requirements set out in Commission Regulation (EC) No 543/2008 (2008).

\section{United States}

Poultry meat products in the US are regulated primarily by the Food Safety and Inspection Service (FSIS) of the United States Department of Agriculture (USDA). The Federal Meat Inspection Act (FMIA; 21 U.S.C. 601-695) and the Poultry Products Inspection Act (PPIA; 21 U.S.C. 451-470) provide the regulations for poultry products. These must be approved by the Secretary of Agriculture, who delegated this authority to the FSIS, before these products can enter commerce. The US Poultry Products Regulations (9 CFR 381.169) state that solutions may be added to ready-to-cook bone-in poultry carcasses and parts, increasing the weight by approximately 3\% over the weight of the raw products after chilling and washing. However, processing technologies such as injection of brine into the muscle tissues, which can incorporate more than $3 \%$ solution into the meat products, have weakened the regulations. Although a liquid solution is initially used to add flavour to raw poultry products without significantly increasing their net weight, a high level of solution increases the total weight of the finished product (FSIS, 2005a). The FSIS requires that all poultry products that retain over $1 \%$ water must be labelled. The regulations for labelling prohibit the distribution of poultry products that are adulterated and misbranded. They also require that the labelling should contain specific information to prevent consumer confusion. Poultry products with solutions that were added in accordance with this regulation must be labelled with a conspicuous legible and descriptive name, including the concise description of the method of addition and function of the added substances such as 'Injected with $2 \%$ water, salt and phosphate solutions' (FSIS, 1974). The labelling of these products must fulfil the labelling compliance quality control criteria stated in 9 CFR 381.169. However, with the publication of the Elimination of Requirements for Partial Quality Control Programs Final Rule (65 FR 34381) on 30 May 2000, the quality control criteria used to monitor the percentage of added solution according to 9 CFR 381.169 is no longer in effect. The 9 CFR 381.169 also does not provide labelling guidance for ready-to-cook bone-in poultry products with solution above $3 \%$ and for boneless poultry products with solutions. Therefore, FSIS issued the Policy Memo 042, "Raw Bone-In Poultry Products Containing Solutions" on February 1982 and the Policy Memo 044A, "Raw Boneless Poultry Containing Solutions" on September 1986 to strengthen the regulations for labelling of enhanced poultry products (FSIS, 2005a).

\section{South Africa}

The DAFF published the first standards for poultry meat processing in March 1992, namely R.946, Regulations regarding Control over the Sale of Poultry Meat. Regulations under R.946 do not mention standards for poultry meat enhancement. This may be because this process was not common practice in 1992. However, R.946 states that when breast meat is treated with a phosphate or other chemical solution, the mass increase of the carcass because of such treatment must not be more than $4 \%$. In addition, the concentration of the phosphate in the solution must not be more than $0.5 \%$. A treatment with a chemical solution may be carried out only on carcasses that contain less than $4 \%$ absorbed moisture (DAFF, 1992). In July 1997 the regulations were revised with R.988, which has an $8 \%$ limitation on the use of brine in whole birds, but is not applicable to brine in individual portions. Because brine enhancement has been practised much more in the poultry industry in recent years, Regulation R.471 was introduced in April 2016 in accordance with R.946 and R.988. With the new regulations, terms such as 'brine' and 'formulated solutions' have been introduced. The absorbed moisture content of 'not exceeding $8 \%$ in water-chilled carcasses' has been changed to $7 \%$ and may be treated with a 'formulated solution'. The wording of R.946-4(9) has been changed from 'phosphate or chemical solution' to 'formulated solution'. The mass increase of the carcass treated with a formulated solution must not exceed $10 \%$ for a whole carcass and $15 \%$ for an individual portion (DAFF, 2016). In addition, the amended regulations in R.471.8(1)(k) (DAFF, 2016) have new labelling guidance for raw processed poultry meat: 'In the case of raw processed poultry meat, the applicable class designation or alternative class designation shall either be preceded or followed by the generic name of the added formulated solution, or by any other wording reflecting a true description of the added formulated solution. E.g. 'chicken with brine', 'sweet 'n sour marinated chicken drumsticks', etc.' This is because some product labels do not clearly and conspicuously identify the ingredients of the added solution 
in the poultry meat or products and cause confusion among consumers. Therefore, labelling guidance is provided in the amended legislation for the poultry industry to develop truthful, easy-to-read labelling information about the added solutions so that consumers can make informed purchase decisions.

\section{Other developing countries}

Developing countries in Africa such as Botswana, Zimbabwe and Namibia practise injection of brine into poultry products for the retail market. Zimbabwe established a $15 \%$ limit for brine addition according to Food Standards Regulations 82/1975 \& 13/1976 (Grynberg \& Motswapong, 2014). The Namibian Biosafety Act No 7 has been legislated in 2006 but no brine level or its limitation has been mentioned. Therefore, there are various levels of brine in poultry products on the market (Grynberg \& Motswapong, 2014). Because Namibia relies largely on imported poultry from South Africa, most of the poultry products in retail have brine levels of about $30 \%$, while the local poultry products have been injected with about 14 to $20 \%$ of brine (Bagopi et al., 2014). In Botswana, brining is not performed on a large scale in the poultry industry and the government has not established a limit for brine level (Grynberg \& Motswapong, 2014). Local poultry producers in Botswana claimed that brine injection in poultry meat should be implemented because the fast food chains require a certain level of brine (Bagopi et al., 2014). On the other hand, in Zambia, local poultry producers do not brine their chickens (Bagopi et al., 2014). Moreover, brined chicken is not allowed to be imported into Zambia (Bronkhorst \& Chongo, 2015). Limited information is shared on the enhancement of poultry products in developing countries worldwide. Studies are therefore required to determine the application of enhancement in developing countries and its effect on the products if poultry meat is to remain a major animal protein source in a balanced human diet. Regulations related to enhancement of poultry meat of these countries (above) are summarized in Table 3.

Table 3. Selected country-specific regulations related to enhancement of poultry meat

\begin{tabular}{|c|c|c|}
\hline Countries/regions & Directive title & Statements related to enhancement \\
\hline $\begin{array}{l}\text { European Union } \\
\text { (EU) }\end{array}$ & $\begin{array}{l}\text { Directive } \\
\text { 71/118/EEC } \\
\text { Directive 94/65/EC } \\
\text { Regulation EU No } \\
1169 / 2011 \text { \& EC } \\
\text { No 543/2008 }\end{array}$ & $\begin{array}{l}\text { The production of meat preparations is controlled } \\
\text { The labelling of pre-packaged poultry meat is standardized with clear } \\
\text { description of content added to the meat product is required }\end{array}$ \\
\hline United States (US) & $\begin{array}{l}\text { Federal Meat } \\
\text { Inspection Act } 21 \\
\text { U.S.C. } 601-695 \\
\text { Regulations } 9 \text { CFR } \\
381.169\end{array}$ & $\begin{array}{l}\text { Solutions can be added to ready-to-cook, bone-in poultry carcasses and } \\
\text { parts, increasing the weight by approximately } 3 \% \text { over the weight of the raw } \\
\text { products }\end{array}$ \\
\hline South Africa & $\begin{array}{l}\text { Regulations R.946 } \\
\text { R.988 } \\
\text { R.471 }\end{array}$ & $\begin{array}{l}\text { The mass increase of the carcass of phosphate or chemical solution } \\
\text { treatment must not be more than } 4 \% \text { of the weight of the meat products } \\
\text { A maximum of } 8 \% \text { of brine can be used for whole birds but not applicable to } \\
\text { individual portions is amended in accordance to R. } 946 \\
\text { Terms such as 'brine' and 'formulated solutions' are introduced. } \\
\text { Amendments of a maximum } 10 \% \text { and } 15 \% \text { of brine can be used for whole } \\
\text { carcass and individual portions, respectively are made in accordance to } \\
\text { R.988 } \\
\text { New labelling quidance in raw processed poultry meat is requlated }\end{array}$ \\
\hline Zimbabwe & $\begin{array}{l}\text { Regulations } \\
82 / 1975 \text { \& 13/1975 }\end{array}$ & A maximum of $15 \%$ of brine can be added to raw poultry products \\
\hline Zambia & $\begin{array}{l}\text { Control of Goods } \\
\text { Act } 22\end{array}$ & $\begin{array}{l}\text { Brined and enhanced chickens are not allowed to be imported into the } \\
\text { country }\end{array}$ \\
\hline $\begin{array}{l}\text { Namibia } \\
\text { Botswana }\end{array}$ & $\begin{array}{l}\text { Namibian Biosafety } \\
\text { Act No } 7 \text { of } 2006 \\
\text { Yet to be legislated }\end{array}$ & No brine level or limitation has been mentioned \\
\hline
\end{tabular}

\section{Controversy over new regulations in South Africa}

The amended regulations for the brine level of poultry products by South African government have not been enforced as planned in March 2016 (The Poultry Site, 2016). Although the poultry industry is in favour of most of the amended regulations, it contests the regulated limits of $10 \%$ and $15 \%$ on whole carcasses and individual portions, respectively. Because the brining level for individual portions and poultry products in the 
market varies from $25 \%$ to $30 \%$, the industry suggests that the new limit should be set at $25 \%$ to ensure the least impact on production and consumer prices (South African Poultry Association (SAPA) v. Minister of Agriculture, 2016). The poultry industry in South Africa believes that the use of brining helps to render poultry meat more affordable for low-income families by selling brined poultry meat at a lower price than normal poultry meat because the retail price is based on net meat weight (South African Poultry Association (SAPA) v. Minister of Agriculture, 2016). The industry reiterated that they are not against brining restrictions, but want brine levels to be economically feasible and practically enforceable (South African Poultry Association (SAPA) v. Minister of Agriculture, 2016). The SAPA speculates that the amended regulations for brine level would render chicken unaffordable for the poor, shrink the local poultry sector, and somehow weaken the outlook for soybean processing and maize production. On the other hand, the SA National Consumers Union (SANCU) believes that enhancement is not necessary because most consumers know how to improve the quality of meat by marinating it at home (Fin24, 2016). Nevertheless, the controversy requires negotiation and tolerance from industry and government for the good of the public on maintaining poultry as an affordable protein source.

\section{Challenges of poultry meat enhancement Challenges during the process of enhancement}

Overall, enhancement improves poultry meat quality in terms of texture, tenderness and juiciness. However, some general problems are associated with the enhancement process in industry. The meat products may exceed the stated label pickup percentage during enhancement. Inconsistent pickup may occur in the same piece of meat or in the same batch. This produces detectable variations in flavour and juiciness (Smith \& Acton, 2001). This may affect consumer acceptability of the batch of enhanced meat. Moreover, formulation errors or unforeseen cooking losses can lead to the meat exceeding the $0.5 \%$ phosphate level in the enhanced product, which leads to complaints of bitterness and dryness of mouthfeel from consumers (Smith \& Acton, 2001). Nevertheless, these problems can be minimized with proper formulation and step-by-step procedures for ensuring consistent application of brine, including following written good manufacturing practices and establishing statistical process control.

\section{Microbiological safety on enhanced poultry meat}

Concerns have been raised that the injection of brine into poultry meat might introduce surface pathogens into the sterile interior of intact meat tissues (Smith \& Acton, 2001). The FSIS categorized moisture enhancement and injection of brine into the meat products as non-intact meat and the poultry industry need to comply with the new Hazard Analysis and Critical Control Points regulations after three outbreaks indicated that E. coli O157:H7 was a hazard in the non-intact meat products (FSIS, 2005b; Laine et al., 2005). The microbiological safety of non-intact, non-comminuted meat may be an issue during preparation of dishes with these meats without thorough cooking at the proper temperature, which destroys pathogenic bacteria in the deep tissue of meat (Lambert et al., 2001; Gill et al., 2009). Contamination has been shown in blade tenderization of beef with E. coli O157:H7 (Phebus et al., 2002), brine-injected pork with Salmonella spp. (Kastner et al., 2001) and needle-injected chicken breast with Clostridium perfringens (Mead \& Adams, 1979). Proper cooking to an appropriate temperature alleviates this drawback, but it remains a problem for enhanced meat products that are marketed in raw form to be cooked at home. There is uncertainty about the health risk that may be posed by bacteria in these deep tissues and the degree of cooking required to assure safe consumption. Further research regarding food safety and bacterial spoilage of moisture-enhanced poultry products is necessary.

Heavy microbial contamination with $E$. coli and pseudomonads may occur with multi-needle injectors when surplus brine is recirculated through the pumping operation and contaminates the surface and interior of meat muscles (Wicklund et al., 2007; Langsrud et al., 2014; Wendler et al., 2017). Recirculation is not a universal practice, but the loss of brine is expensive and could cause effluent disposal problems (Varnam \& Sutherland, 1995). High microbial loads are considered undesirable in injection brines, which may shorten the shelf-life of meat products and pose potential health risks to consumers. Various methods are currently being studied to reduce microbial load in recirculated brine, including filtration, centrifugation and ultraviolet irradiation (Chemat et al., 2011).

\section{Controversy of high salt content in enhanced poultry meat}

Most current enhancements use brine with a high sodium chloride content. Sodium occurs naturally in poultry meats ranging from $68 \mathrm{mg}$ per $100 \mathrm{~g}$ to $77 \mathrm{mg}$ per $100 \mathrm{~g}$ meat (equivalent to salt content of 0.17 to $0.20 \mathrm{~g}$ per $100 \mathrm{~g}$ of meat) (USDA, 2005; FSA, 2006). Brine-enhanced poultry meat products contain high salt concentration of $200 \mathrm{mg}$ to $500 \mathrm{mg}$ of sodium per $100 \mathrm{~g}$ (USDA, 2005). The recommended intake for dietary sodium is no higher than $2000 \mathrm{mg}$ per day for a healthy individual and $1500 \mathrm{mg}$ per day for high-risk 
individuals (World Health Organization (WHO), 2012). Excessive sodium intake has serious implications for human health, especially the development of hypertension (MacGregor \& de Wardener, 2002; Desmond, 2006; De Kock et al., 2016). As a result, public health and regulatory authorities from developed and developing countries have implemented strategies to get consumers and the food industry to reduce their sodium intake and usage in food (Desmond, 2006). Population-based interventions aimed at reducing salt consumption are implemented according to the sodium or salt guidelines in overall food-based dietary guidelines worldwide. For example, South Africa stresses that salt intake should be reduced to less than $6 \mathrm{~g}$ per day (De Kock et al., 2016), Singapore and Bangladesh encourage the reduction of salt intake to $5 \mathrm{~g}-10 \mathrm{~g}$ per day (Wentzel-Viljoen et al., 2013). However, from a food chemistry perspective, sodium plays important roles in contributing to taste, as a functional ingredient in certain formulations, and as part of the integral microstructure of many food products (Desmond, 2006). It is also important to consider consumers' taste perceptions and liking for reduced-salt food products. Replacement of $\mathrm{NaCl}$ may cause changes in odour, taste and consistency (Schoene et al., 2009). Guven \& Karaca (2001), Blesa et al. (2008) and Horita et al. (2014) reported the use of potassium chloride $(\mathrm{KCl})$ and calcium chloride $\left(\mathrm{CaCl}_{2}\right)$ as $\mathrm{NaCl}$ replacements in frankfurters, cured ham and salted cheese. But $\mathrm{KCl}$ gives a bitter taste, which consumers may find unacceptable (Albarracín et al., 2011). Phosphate substitutes such as sodium pyrophosphates and sodium tripolyphosphate also enhance the water-holding capacity and salty taste in chicken frankfurters formulated with a reduction in salt by $20 \%$ and $40 \%$ (Ruusunen \& Puolanne, 2005; Alvarado \& McKee, 2007). Because salt and fat contribute to the sensory properties in meat (Matulis et al., 1995), flavour enhancers and masking agents such as yeast extracts, lactates and monosodium glutamate are used to compensate for salt reduction by activating taste receptors in the mouth and throat (Brandsma, 2006; Searby, 2006; Romero de Ávila et al., 2010). However, a high level of glutamate has been associated with the 'Chinese restaurant syndrome', and may cause headaches, swelling and weakness (Durack et al., 2008). Therefore, recent research had focused on the use of $\mathrm{NaCl}$ substitutes in reducing salt concentration in brine solution, enhancing water-holding capacity of meat and limiting lipid oxidation, but without affecting the taste of meat.

Studies on consumer acceptance of brine treated or enhanced poultry meat are scarce. Betti et al. (2009) reported that consumer acceptability of texture, flavour, liking and overall opinion on chicken enhanced with omega-3 polyunsaturated fatty acids was similar to that of non-treated chicken. Research into meat quality associated with consumer acceptance by Miller et al. (2001) revealed that tenderness, juiciness, flavour and overall palatability were the most sought-after attributes by consumers. Therefore, an enhancement process that improves tenderness, juiciness and flavour of poultry meat would be accepted by consumers. Nevertheless, some health-conscious consumers may not have positive views on enhanced meat that contains a high salt concentration, even though the meat quality is improved (Troy \& Kerry, 2010). Therefore, it is suggested that consumers might accept the enhancement of poultry meat if the quality is improved with an acceptable salt level. Further research is crucial to identify and verify the consumer acceptance of enhanced poultry meat in various countries.

\section{Future implications and conclusions}

The production and consumption of poultry meat has undergone remarkable growth in recent years because of advances in food-processing technology. As a result, methods of enhancement have evolved from simple immersion to complicated pulsed vacuum injection to improve quality, and increase the value and shelf life of poultry meat products. Although enhancement does not have an apparent effect on the nutritional profile of poultry meat, it affects its sodium and phosphorus content and compliance with recommended dietary intake of these minerals in consumers. The development of country-specific food policies, regulations and dietary guidelines is influenced largely by international obligations in combating food waste and making food systems more available, accessible and nutritious. It is still debatable which practice has a more positive impact on product quality, the intake of sodium, and value-to-cost benefit. Future product development research should focus on minimizing the concentrations of salt and phosphate in the brine, improving the tenderness of meat and incorporating other flavours and functional ingredients in enhanced meat. Efforts, including in-brine recirculation operations, should be made to minimize microbial contamination and extend the shelf life of meat to ensure long-term product stability and safety. Brine formulations to control foodborne pathogens in enhanced meat should be improved and developed for industrial application and meet public health guidelines.

\section{Acknowledgements}

The University of Pretoria Postdoctoral Fellowship Program is acknowledged for providing financial support. The Australia Africa University Network (AAUN) donated the grant that made this collaboration possible.

\section{Authors' Contributions}


SMT conceptualized and drafted the review article. HLdK, GAD, RC and EMB contributed to the development, revision and editing of the article. All authors read and approved the final version.

\section{Conflict of Interest Declaration}

The authors declare there is no conflict of interest.

\section{References}

Adler-Nissen, J. \& Olsen, H.S., 1979. The influence of peptide chain length on taste and functional properties of enzymatically modified soy protein. In: Functionality and protein structure. Edited by A. Pour-El. American Chemical Society, Washington, DC. pp. 125-147.

Albarracín, W., Sánchez, I.C., Grau, R. \& Barat, J.M., 2011. Salt in food processing; Usage and reduction: A review. Int. J. Food Sci Technol. 46, 1329-1336.

Alvarado, C. \& McKee, S., 2007. Marination to improve functional properties and safety of poultry meat. J. Appl. Poultry Res. 16, 113-120.

Amako, D.E.N. \& Xiong, Y.L., 2001. Effects of carrageenan on thermal stability of proteins from chicken thigh and breast muscles. Food Res. Int. 34, 247-253.

American Meat Institute, 2007. Meat matters: Consumer's guide to enhanced meats. Available at: http://www.meatmattersinfo.org/enhanced-meats/

Association of Poultry Processors and Poultry Trade in the EU (AVEC), 2016. Annual report 2016. Available at: http://www.avec-poultry.eu/system/files/archive/new-structure/avec/Annual_Report/2016/AR\%201-52\%20(17-0816)\%20BAT.pdf

Awad, T.S., Moharram, H.A., Shaltout, O.E., Asker, D. \& Youssef, M.M., 2012. Applications of ultrasound in analysis, processing and quality control of food: A review. Food Res. Int. 48, 410-427.

Ayadi, M.A., Kechaou, A., Makni, I. \& Attia, H., 2009. Influence of carrageenan addition on turkey meat sausages properties. J. Food Eng. 93, 278-283.

Bagopi, E., Chokwe, E., Halse, P., Hausiku, J., Kalapula, W., Humavindu, M. \& Roberts, S., 2014. Competition dynamics and regional trade flows in the poultry sector: The case of South Africa, Botswana, Namibia and Zambia. Available http://agriprofocus.com/upload/post/2014_Poultry_Trade_flows_in_S_Africa_Botswana_Namibia_Zambia_ICN_C onfpaper1443600533.pdf.

Bajovic, B., Bolumar, T. \& Heinz, V., 2012. Quality considerations with high pressure processing of fresh and valueadded meat products. Meat Sci. 92, 280-289.

Belova, A.V., Smutka, L. \& Rosochatecká, E., 2012. World chicken meat market - its development and current status. Acta Univ Agric Silvic Mendel Brun, Lx (2), 15-20.

Betti, M., Schneider, B.L., Wismer, W.V., Carney, V.L., Zuidhof, M.J. \& Renema, R.A., 2009. Omega-3-enriched broiler meat: 2. Functional properties, oxidative stability, and consumer acceptance. Poult. Sci. 88, 1085-1095.

Blesa, E., Alino, M., Barat, J.M., Grau, R., Toldrá, F. \& Pagán, M.J., 2008. Microbiology and physico-chemical changes of dry-cured ham during the post-salting stage as affected by partial replacement of $\mathrm{NaCl}$ by other salts. Meat Sci. 78, 135-142.

Brandsma, I., 2006. Reducing sodium: A European perspective. Food Technol. 60, 25-29.

Brewer, M.S., Jensen, J., Prestat, C., Zhu, L.G. \& McKeith, F.K., 2002. Visual acceptability and consumer purchase intent of enhanced pork loin roasts. J. Muscle Foods 13(1), 53-68.

Bronkhorst, B. \& Chongo, R.M., 2015. Market study - poultry: Investment opportunities in the Zambian poultry sector (and in the Katanga region of the DR Congo). Available at: http://agriprofocus.com/upload/Final_Market_Study_of_Poultry_Sector_in_Zambia_(for_publication)1445864268. pdf

Cael, M., Howe, J., Patterson, K.K., Holden, J.M., Showell, B.A., Luna, A. \& Thompson, L.D., 2009. Nutrient composition of enhanced and non-enhanced boneless skinless chicken breast fillets purchased from retail. Paper presented at 2009 Reciprocal Meat Conference, Rogers, Arkansas. Available at: https://www.ars.usda.gov/research/publications/publication/?seqNo115=239039

Cárcel, J.A., Benedito, J., Bon, J. \& Mulet, A., 2007. High intensity ultrasound effects on meat brining. Meat Sci. 76, 611619.

Chemat, F., Zill-e-Huma \& Khan, M.K., 2011. Applications of ultrasound in food technology: Processing, preservation and extraction. Ultrason. Sonochem 18, 813-835.

Chin, K.B., Go, M.Y. \& Xiong, Y.L., 2009. Effect of soy protein substitution for sodium caseinate on the transglutaminateinduced cold and thermal gelation of myofibrillar protein. Food Res. Int. 42, 941-948.

Chiralt, A., Fito, P., Barat, J.M., Andrés, A., González-Martínez, C., Escriche, I. \& Camacho, M.M., 2001. Use of impregnation in food salting process. J. Food Eng. 49, 141-151.

Council of European Union, 1994. Council Directive 94/65/EC. Available at: http://eur-lex.europa.eu/legalcontent/EN/ALL/?uri=CELEX\%3A31994L0065R(01)

Davies, K.J., Sebranek, J.G., Huff-Lonergan, E. \& Lonergan, S.M., 2004. The effects of aging on moisture-enhanced pork loins. Meat Sci. 66, 519-524.

De Kock, H.L., Zandstra, E.H., Sayed, N. \& Wentzel-Viljoen, E., 2016. Liking, salt taste perception and use of table salt when consuming reduced-salt chicken stews in light of South Africa's new salt regulations. Appetite 96, 383-390. 
Department of Agriculture, Forestry and Fisheries (DAFF), 1992. Agricultural Product Standards Act 1990 (Act No.119). Available at: http://www.daff.gov.za/daffweb3/Branches/Agricultural-Production-Health-Food-Safety/Food-SafetyQuality-Assurance/Local-and-Import-Regulations/Animal-Products

Department of Agriculture, Forestry and Fisheries (DAFF), 2013. A profile of the South African broiler market value chain - 2013. Available at: http://www.daff.gov.za/daffweb3/Resource-Centre:1-51

Department of Agriculture, Forestry and Fisheries (DAFF), 2016. Amendments of Agricultural Product Standards Act 1990 (Act No.119). R.471. Available at: http://www.nda.agric.za/doaDev/sideMenu/foodSafety/doc/locallmportRegulations/Poultry\%20471.pdf

Desmond, E., 2006. Reducing salt: A challenge for the meat industry. Meat Sci. 74, 188-196.

Deumier, F.C., Trystram, G., Collignan, A., Guédider, L. \& Bohuon, P., 2003. Pulsed vacuum brining of poultry meat: Interpretation of mass transfer mechanisms. J. Food Eng. 58, 85-93.

Durack, E., Alonso, M. \& Wilkinson, M.G., 2008. Salt: a review of its role in food science and public health. Curr. Nutr. Food Sci. 4, 290-297

Egbert, W.R. \& Payne, C.T., 2009. Plant proteins. In: Ingredients in meat products: Properties, functionality and applications. Ed ited by R. Tarté. Springer Science \& Business Media, US. pp.124-125.

Ensminger, M.E. \& Ensminger, A.H., 1993. Food \& nutrition encyclopedia, two volume set. CRC Press, US.

Feiner, G., 2006. Meat products handbook. Woodhead, Cambridge, UK.

Feng, J. \& Xiong, Y.L., 2003. Interaction and functionality of mixed myofibrillar and enzyme-hydrolyzed soy proteins. J. Food Sci. 68, 803-809.

Fito, P. \& Pastor, R., 1994. Non-transferal mechanisms occurring during vacuum osmotic dehydration. J. Food Eng. 21, 513-519.

Fin24, 2016. Chicken brining rules will devastate SA, poultry body warns (Press release). Available at: http://www.fin24.com/Economy/chicken-brining-rules-will-devastate-sa-poultry-body-warns-20160504

Food and Agricultural Organization of the United Nation (FAO), 2012. Meat and meat products market summary. Available http://www.fao.org/fileadmin/templates/est/COMM_MARKETS_MONITORING/Meat/Documents/June_2012.pdf.

Food Standards Agency (FSA), 2000. Survey of added water in chickens and chicken parts. Food Surveillance Information Sheet No. 8/00.

Food Standards Agency (FSA), 2006. Salt reduction targets. Available at: http://www.food.gov.uk/multimedia/pdfs/salttargetsapril06.pdf

Gill, C.O., Moza, L.F. \& Barbut, S., 2009. Survival of bacteria in less than through cooked, brine-injected steaks. Food Control, 29, 501-507.

Gómez, J., Sanjuán, N., Bon, J., Arnau, J. \& Clemente, G., 2015. Effect of temperature on nitrite and water diffusion in pork meat. J. Food Eng. 149, 188-194.

Graiver, N., Pinotti, A., Califano, A. \& Zaritzky, N., 2006. Diffusion of sodium chloride in pork tissue. J. Food Eng. 77(4), 910-918.

Graiver, N., Pinotti, A., Califano, A. \& Zaritzky, N., 2009. Mathematical modelling of the uptake of curing salts in pork meat. J. Food Eng. 95(4), 533-540.

Grynberg, R. \& Motswapong, M., 2014. Competition and trade policy: the case of the Botswana poultry industry. Available at: http://www.compcom.co.za/wp-content/uploads/2014/09/GrynbergMotswapong.pdf

Guardian, The, 2013. Supermarkets selling chicken that is nearly a fifth water (Press release). Available at: https://www.theguardian.com/world/2013/dec/06/supermarket-frozen-chicken-breasts-water.

Guven, M. \& Karaca, O.B., 2001. Proteolysis levels of white cheeses salted and ripened in brines prepared from various salts. Int. J. Dairy Technol. 54, 29-33.

Guyon, C., Meynier, A. \& de Lamballerie, M., 2016. Protein and lipid oxidation in meat: A review with emphasis on highpressure treatments. Trends Food Sci. Technol. 50, 131-143.

Hatloe, J., 1995. Methods for pickling and/or marinating non-vegetable foodstuff raw material. International Patent WO 9518537.

Hayes, J.E., Desmond, E.M., Troy, D.J., Buckley, D.J. \& Mehra, R., 2006. The effect of enhancement with salt, phosphate and milk proteins on the physical and sensory properties of pork loin. Meat Sci. 72, 380-386.

Horita, C.N., Messias, V.C., Morgano, M.A., Hayakawa, F.M. \& Pollonio, M.A.R., 2014. Textural, microstructural and sensory properties of reduced sodium frankfurter sausages containing mechanically deboned poultry meat and blends of chloride salts. Food Res. Int. 66, 29-35.

Jin, G., He, L., Wang, Q., Liu, C., Jin, Y., Huang, F. \& Ma, M., 2014. Pulsed pressure assisted brining of porcine meat. Innov. Food Sci. Emerg. Technol. 22, 76-80.

Joubert, J., Norman, R., Bradshaw, D., Goedecke, J.H., Steyn, N.P. \& Puoane, T., 2007. Estimating the burden of disease attributable to excess body weight in South Africa in 2000. S. Afr. Med. J. 97, 683-690.

Juliano, B.O., 1993. Rice in human nutrition. FAO, Rome. pp.17-34.

Kastner, C.L., Phebus, R.K., Thippareddi, H., Mardsen, J.L., Karr Getty, K.J., Danler, B., ... Schwenke, J.R., 2001. Meat technology and processing - Current issues and trends. 47th ICoMST 2001, pp.68-71.

Kiker, J., Howe, J., Holden, J.M., Boyce, J., Luna, A., Alvarado, C., Wester, D. \& Thompson, L.D., 2007. Nutritional composition of fried and raw enhanced or non-enhanced chicken breast fillets. Paper presented at Poultry Science Association Annual Meeting, San Antonio, Texas, United States.

Knight, P. \& Parsons, N., 1988. Action of $\mathrm{NaCl}$ and polyphosphates in meat processing: Responses of myofibrils to concentrated salt solutions. Meat Sci. 24, 275-300. 
Laine, E.S., Scheftel, J.M., Boxrud, D.J., Vought, K.J., Danila, R.N., Elfering, K.M. \& Smith, K.E., 2005. Outbreak of Escherichia coli O157:H7 infections associated with non-intact, blade-tenderized frozen steaks sold by door-todoor vendors. J. Food Protect. 68, 1198-1202.

Lamballeric-Anton, M., de Taylor, N.R. \& Culioli, J., 2002. High pressure processing of meat. In: Meat processing: Improving quality. Edited by D.B, Macdougall, J. Kerry, \& D. Ledward, CRC Press, Boca Raton, FL. pp. 313-324.

Lambert, D.L., Phebus, R.K., Thippareddi, H., Marsden, J.L. \& Ka stner, C.L., 2001. Salmonella spp. risk assessment for production and cooking of non-intact pork products. Abstract book of 88th Annual Meeting of International Association for Food Protection. International Association of Milk, Food and Environmental Sanitarians, lowa, United States. p. 60.

Langsrud, S., Heir, E. \& Rode, T.M., 2014. Survival of Shiga toxin-producing Escherichia coli and Stx bacteriophages in moisture enhanced beef. Meat Sci. 97, 339-346.

Leng, X., Zhang, L., Huang, M., Xu, X. \& Zhou, G., 2013. Mass transfer dynamics during high pressure brining of chicken breast. J. Food Eng. 118, 296-301.

MacGregor, G.A. \& de Wardener, H.E., 2002. Salt, blood pressure and health. Int. J. Epidemiology, 31, 320-327.

Matulis, R.J., McKeith, F.K., Sutherland, J.W. \& Brewer, M.S., 1995. Sensory characteristics of frankfurters as affected by fat, salt and $\mathrm{pH}$. J. Food Sci. $60,42-47$.

Mead, G. \& Adams, B., 1979. Microbiological aspects of polyphosphate injection in the processing and chill storage of poultry. J. Hyg. 82, 133-142.

Miller, M.F., Carr, M.A., Ramsey, C.B., Crockett, K.L. \& Hoover, L.C., 2001. Consumer thresholds for establishing the value of beef tenderness. J. Anim. Sci, 79, 3062-3068.

Nguyen, M.V., Arason, A., Thorarinsddottir, K.A., Thorkelsson, G. \& Gudmundsdóttir, A., 2010. Influence of salt concentration on the salting kinetics of cod loin (Gadus morhua) during brine salting. J. Food Eng. 100(2), 225231.

Offer, G. \& Knight, P., 1988. The structural basis of water holding in meat. Part 1: General principles and water uptake in meat processing. In: Developments in meat science, vol. 4. Edited by R. Lawrie., Elsevier Science, London. pp. 63-171.

Offer, G. \& Trinick, J., 1983. On the mechanism of the water holding in meat: The swelling and shrinking of myofibrils. Meat Sci. 8(4), 245-281.

Pandurevic, T., Mitrovic, S., Ristanovic, B. \& Stanisic, V., 2014. Quality of chicken meat from conventional and organic production. Proceedings of the $5^{\text {th }}$ International Scientific Agricultural Symposium East Sarajevo, Jahorina, Faculty of Agriculture. pp. 849-853.

Phebus, R.K., Mardsen, J.L., Thippareddi, H., Sporing, S. \& Ortega, T., 2002. Escherichia coli O157:H7 risk assessment for production and cooking of blade tenderized beef steaks. Paper presented at USDA-FSIS public meeting on E. coli O157:H7 policy, Arlington, Virginia. pp.1-4.

Pietrasik, Z., Gaudette, N.J. \& Johnston, S.P., 2016. The use of high pressure processing to enhance the quality and shelf life of reduced sodium naturally cured restructured cooked hams. Meat Sci. 116, 102-109.

Poultry Site, The, 2016. Poultry brining regulations still on ice (Press release). Available at: http://www.thepoultrysite.com/poultrynews/36729/poultry-brining-regulations-still-on-ice.

Puolanne, E.J., Ruusunen, M.H. \& Vainionpää, J.I., 2001. Combined effects of $\mathrm{NaCl}$ and raw meat pH on water-holding in cooked sausage with and without added phosphate. Meat Sci. 58, 1-7.

Ranken, M.D., 2000. Handbook of meat product technology. Blackwell Science, Oxford, UK.

Robbins, K., Jensen, J., Ryan, K.J., Homco-Ryan, C., McKeith, F.K. \& Brewer, M.S., 2002. Enhancement effects on sensory and retail display characteristics of beef rounds. J. Muscle Foods 13, 279-288.

Romero de Ávila, M.D., Ordónez, J.A., de la Hoza, L., Herrero, A.M. \& Cambero, M.I., 2010. Microbial transglutaminase for cold-set binding of unsalted/salted pork models and restructured dry ham. Meat Sci. 84, 747-754.

Rural Industries Research and Development Corporation (RIRDC), 2014. Chicken meat program five year RD\&E plan 2014-2019. Available at: http://www.rirdc.gov.au/research-programs/animal-industries/chicken-meat

Ruusunen, M. \& Puolanne, E., 2005. Reducing sodium intake from meat products. Meat Sci. 70, 531-541.

Sabadini, E., Carvalho, B.C. Jr., Sobral, P.J. do A. \& Hubinger, M.D., 1998. Mass transfer and diffusion coefficient determination in the wet and dry salting of meat. Drying Technol. 16, 2095-2115.

Sanchez, E.S., Simal, S., Femenia, A., Benedito, J. \& Rossello, C., 1999. Influence of ultrasound on mass transport during cheese brining. Eur. Food Res. Technol. 209, 215-219.

Schoene, F., Mnich, K., Jahreis, G. et al., 2009. Analysis of meat products produced with mineral salt constituents. Fleischwirtschaft 89, 149-152.

Searby, L., 2006. Pass the salt. International Food Ingredients (February/March), 6-8.

Shi, J. \& Le Maguer, M., 2002. Osmotic dehydration of foods: mass transfer and modelling aspects. Food Rev. Int. 18(4), 305-335.

Smith, D.P. \& Acton, J.C., 2001. Marination, cooking and curing of poultry products. In: Poultry meat processing. Edited by A.R., Sams. CRC Press, Boca Raton, FL. pp. 257-280.

Smith, L.C. \& Wiesman, D., 2007. Is food security more severe in South Asia or sub-Saharan Africa? International Food Policy Research Institute Discussion Paper, 712, 52. Available at: http://ageconsearch.umn.edu/bitstream/42401/2/ifpridp00712.pdf

South African Poultry Association (SAPA) v. Minister of Agriculture, 2016. ZAGPPHC 862 (21 September 2016) Court case documents no. 39597/2016. Available at: http://www.saflii.org/za/cases/ZAGPPHC/2016/862.html

South African Poultry Association (SAPA), 2015. South Africa Country Report. Available at: https://www.sapoultry.co.za/pdf-statistics/south-africa-country-report.pdf 
Tamm, A., Bolumar, T., Bajovic, B. \& Toepfl, S., 2016. Salt (NaCl) reduction in cooked ham by a combined approach of high pressure treatment and the salt replacer KCl. Innov. Food Sci. Emerg. Technol. 36, 294-302.

Troy, D.J. \& Kerry, J.P., 2010. Consumer perception and the role of science in the meat industry. Meat Sci. 86, 214-226.

US Food Safety and Inspection Service (FSIS), 1974. US Poultry Products Regulations 9 CFR 381.169. Available at: https://www.gpo.gov/fdsys/granule/CFR-2010-title9-vol2/CFR-2010-title9-vol2-sec381-169/content-detail.html

US Food Safety and Inspection Service (FSIS), 2005a. FSIS Policy Memoranda. Available at: http://www.fsis.usda.gov/OPPDE/larc/Policies/Policy_Memos_082005.pdf

US Food Safety and Inspection Service (FSIS), 2005b. HACCP plan reassessment for mechanically tenderized beef product. Federal Register, 70, 30331-30334.

US Food Safety and Inspection Service (FSIS), 2016. FSIS Directive 7120.1 Safe and suitable ingredients used in the production of meat, poultry, and egg products. Available at: http://www.fsis.usda.gov/wps/wcm/connect/bab10e09-aefa-483b-8be8809a1f051d4c/7120.1.pdf?MOD=AJPERES

United States Department of Agriculture (USDA), 2005. Food nutrient database, version SR18. Available at: http://www.nal.usda.gov/fnic/foodcomp/Data/SR18/sr18.html

United States Department of Agriculture (USDA), 2016. The biannual report of livestock and poultry: World markets and trades. Available at: http://apps.fas.usda.gov/psdonline/circulars/livestock_poultry.pdf

Varnam, A. \& Sutherland, J.P., 1995. Meat \& meat products: Technology, chemistry and microbiology. Springer Science \& Business Media, US.

Vestegaard, C., Risum, J. \& Adler-Nissen, J., 2005. ${ }^{23} \mathrm{Na}-\mathrm{MRI}$ quantification of sodium and water mobility in pork during brine curing. Meat Sci. 69, 663-672.

Villacís, M.F., Rastogi, N.K. \& Balasubramaniam, V.M., 2008. Effect of high pressure on moisture and $\mathrm{NaCl}$ diffusion into turkey breast. LWT - Food Sci. Technol. 41, 836-844.

Wang, D., Tang, J. \& Correia, L., 2000. Salt diffusivities and salt diffusion in farmed Atlantic salmon muscle as influenced by rigor mortis. J. Food Eng. 43, 115-123.

Wang, Z., Xu, W., Kang, N., Shen, Q. \& Zhang, D., 2016. Microstructural, protein denaturation and water holding properties of lamb under pulse vacuum brining. Meat Sci. 113, 132-138.

Wendler, K.R., Nattress, F.M., Roberts, J.C., Larsen, I.L. \& Aalhus, J.L., 2017. Bacteriology and meat quality of moisture enhanced pork from retail markets in Canada. J. Food Res. 6, 95-103.

Wentzel-Viljoen, E., Steyn, K., Ketterer, E. \& Charlton, K.E., 2013. 'Use salt and foods high in salt sparingly': A foodbased dietary guideline for South Africa. S. Afr. J. Clin. Nutri. 26, S105-S113.

Wicklund, R., Paulson, D.D., Rojas, M.C. \& Brewer, M.S., 2007. The effects of shelf-life enhancers on E. coli K12 survival in needle-injected, surface contaminated beef strip steaks enhanced using recycled solutions. Meat Sci. 75, 371-380.

Williams, J.R., Roseland, J.M., Howe, J.C., Patterson, K.Y., Thompson, L.D., Luna, A.M. \& Fairly, S., 2013. Nutrient comparison between enhanced and non-enhanced fresh whole turkey. Paper presented at the 37th National Nutrient Databank Conference, Boston, Massachusetts.

Williams, J.R., Roseland, J.M., Nguyen, Q.V., Howe, J.C., Patterson, K.Y. \& Thompson, L.D., 2014. Nutrient comparison for enhanced and non-enhanced chicken breasts. Paper presented at IFT 14 Annual Meeting and Food Expo, New Orleans, Louisiana.

Wilson, W.G., 2008. Wilson's practical meat inspection. John Wiley \& Sons, US.

World Health Organization (WHO), 2012. Guideline: Sodium intake for adults and children. Available at: http://www.who.int/nutrition/publications/guidelines/sodium_intake/en/.

Xargayó, M., Lagares, E., Fernández, E., Ruiz, D. \& Borrell, D., 2001. Marination of fresh meats by means of spray effect: influence of spray injection on the quality of marinated products. Available at: http://www.metalquimia.com/images/doctecnologic/art13.pdf

Xiong, Y., Lou, X., Harmon, R., Wang, C. \& Moody, W., 2000. Salt and pyrophosphate-induced structural changes in myofibrils from chicken red and white muscle. J. Sci. Food Agri. 80(8), 1176-1182.

Xiong, Y.L., 2005. Role of myofibrillar proteins in water-binding in brine-enhanced meats. Food Res. Int. 38, $281-287$. 